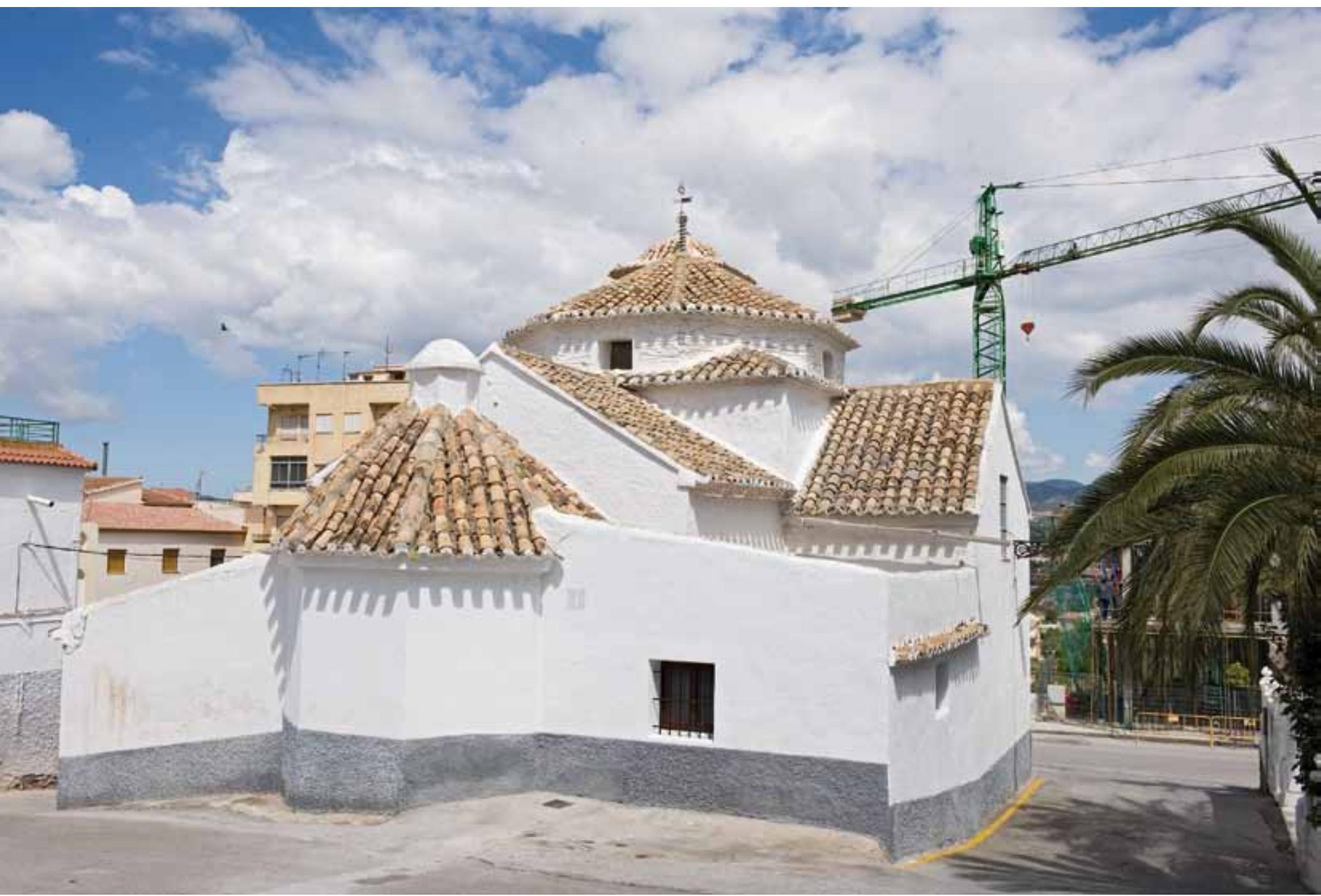

Iglesia de Nuestra Señora de la Concepción en Tíjola.

Foto: Fondo Gráfico IAPH (Juan Carlos Cazalla) 


\section{El inventario de bienes muebles del patrimonio histórico de la Iglesia Católica en el valle del Almanzora}

Gloria Espinosa Spinola, Universidad de Almería; Miguel Ángel Sorroche Cuerva, Universidad de Granada

Los inventarios de los bienes muebles pertenecientes a la Iglesia Católica se iniciaron en Andalucia en el año 1989 en la Archidiócesis de Granada. Paulatinamente las diversas archidiócesis y diócesis andaluzas fueron objetos de dichos trabajos, siendo la provincia de Almeria una de las últimas en incorporarse a este proceso en el año 2004. Fue entonces cuando se comenzó el inventario de bienes muebles del obispado almeriense en el marco de los contratos de investigación firmados con la Dirección General de Bienes Culturales de la Consejeria de Cultura de la Junta de Andalucia y, posteriormente, en una segunda fase, gracias al convenio suscrito entre la Universidad de Almería y la Dirección General de Bellas Artes y Bienes Culturales del Ministerio de Cultura. Se formó entonces un equipo encabezado por Gloria Espinosa Spínola y Miguel Ángel Sorroche Cuerva, profesores de historia del arte de las universidades de Almería y Granada respectivamente, e integrado por un grupo de profesionales especializados en las distintas disciplinas necesarias en la catalogación de bienes muebles. María del Rosario Torres Fernández, Ana Ruiz Gutiérrez y Alfredo Ureña Uceda, profesores universitarios de historia del arte, han sido los encargados de la investigación de las obras de arte inventariadas; María José Estremera Linares, licenciada en bellas artes en la especialidad del restauración, ha realizado la valoración del estado del conservación de las diferentes piezas y, por último, el fotógrafo Roberto Travesí Idáñez, se ha encargado de la documentación gráfica imprescindible en un trabajo de estas características. Además, el equipo ha contado con la colaboración de Francisco Fernández Lao, delegado de patrimonio cultural del obispado almeriense, como interlocutor con los párrocos y responsables de las órdenes religiosas de los inmuebles inventariados.

Entre los años 2004 y 2010 el equipo ha inventariado 39 edificios repartidos por toda la provincia almeriense con un total de 1.257 bienes muebles. Como premisa de trabajo, se partió de un hecho fundamental: la sistemática destrucción del patrimonio artístico de Almería durante los dos últimos siglos, con episodios especialmente hirientes como los acontecidos durante la guerra civil de 1936. Se perdieron entonces significativas maquinarias barrocas como por ejemplo el retablo mayor de la iglesia de la Encarnación de Fiñana del primer cuarto del siglo XVII realizado por el artista accitano Miguel Freyla o el retablo mayor del santuario del Saliente en Albox de finales del siglo XVIII, además de un gran número de imágenes, pinturas de devoción y piezas de los ajuares eclesiásticos. Esta merma determinó que durante la segunda mitad del siglo XX se fuera incrementando el patrimonio almeriense con diversas aportaciones en el campo de la retablística, la escultura y la pintura principalmente, con el fin de cubrir el vacio litúrgico y ornamental sufrido por muchos de sus templos tras la guerra civil. Por estas razones, y aunque, evidentemente, los criterios de selección de las piezas inventariadas han sido los establecidos a priori por el IAPH para todo el patrimonio mueble andaluz y que limita la inclusión de piezas realizadas a partir de 1900, en el caso de la provincia de Almeria, se han investigado e incluido en el inventario los casos más significativos de piezas contemporáneas e, incluso, coetáneas, que bien siendo de buena calidad artística, bien por la relevancia devocional que han ido adquiriendo en la comunidad religiosa, responden al esfuerzo de los almerienses por dignificar y enriquecer sus templos y parroquias. Como ejemplos ilustrativos de estos trabajos en la comarca del valle del Almanzora, podemos mencionar el retablo camarin de Nuestra Señora del Buen Retiro de los Desamparados del monasterio del Saliente en Albox, obra neobarroca realizada en 1988, asi como los aderezos en plata que adornan a esta magnífica escultura de principios del siglo XVIII, como la corona y la peana, esta última pieza realizada en Granada en el año 1981 en los Talleres de Arte Moreno. Los retablos e imágenes salidas del prestigioso taller del artista almeriense Jesús de Perceval, muy solicitado durante toda la posguerra, como son el retablo de San José y el púlpito de la iglesia de la Encarnación de Cuevas del Almanzora. También es de interés el caso de la escultura de bulto redondo de Nuestra Señora del Rosario que se encuentra en la ermita de la Virgen del Socorro de Tíjola, obra realizada en 1941 por un escultor valenciano, siguiendo como modelo la pieza perdida en 1936. Caso a tener en cuenta ya que se ha repetido con otras obras en toda la provincia almeriense. 


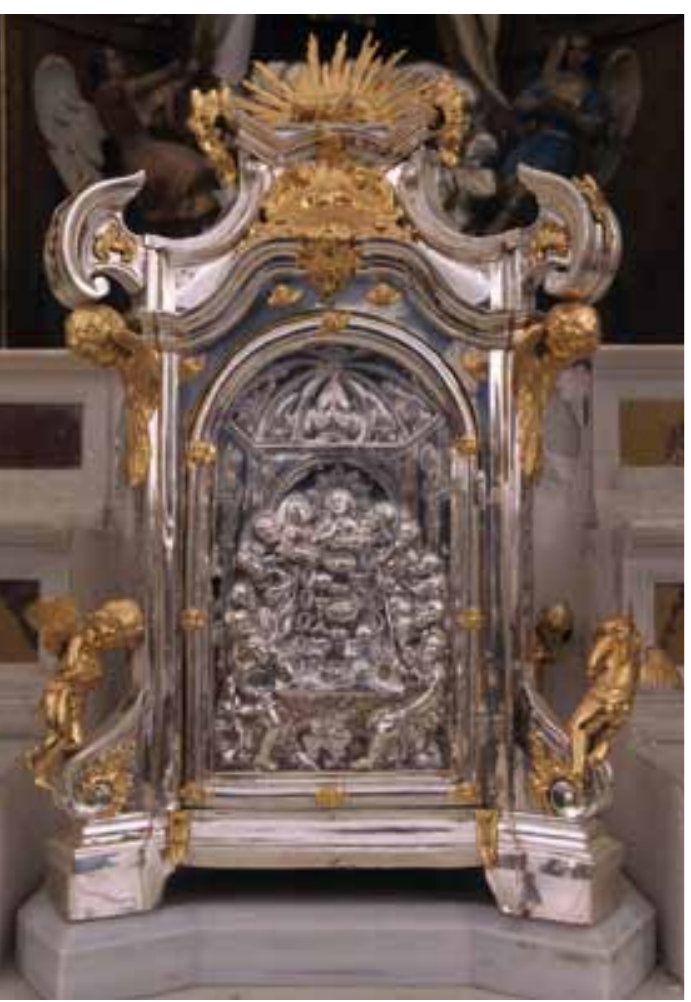

Arca Eucarística de Cuevas del Almanzora Fotos: Roberto Travesí ldáñez lde todas las imágenes del artículo, si no se indica lo contrario)

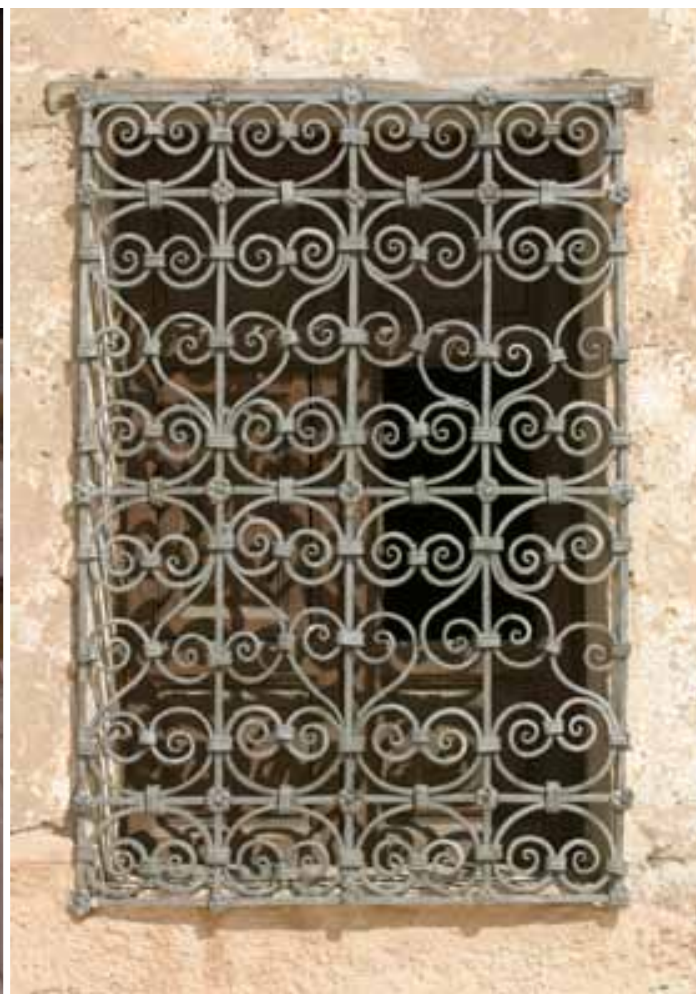

Reja del santuario del Saliente en Albox

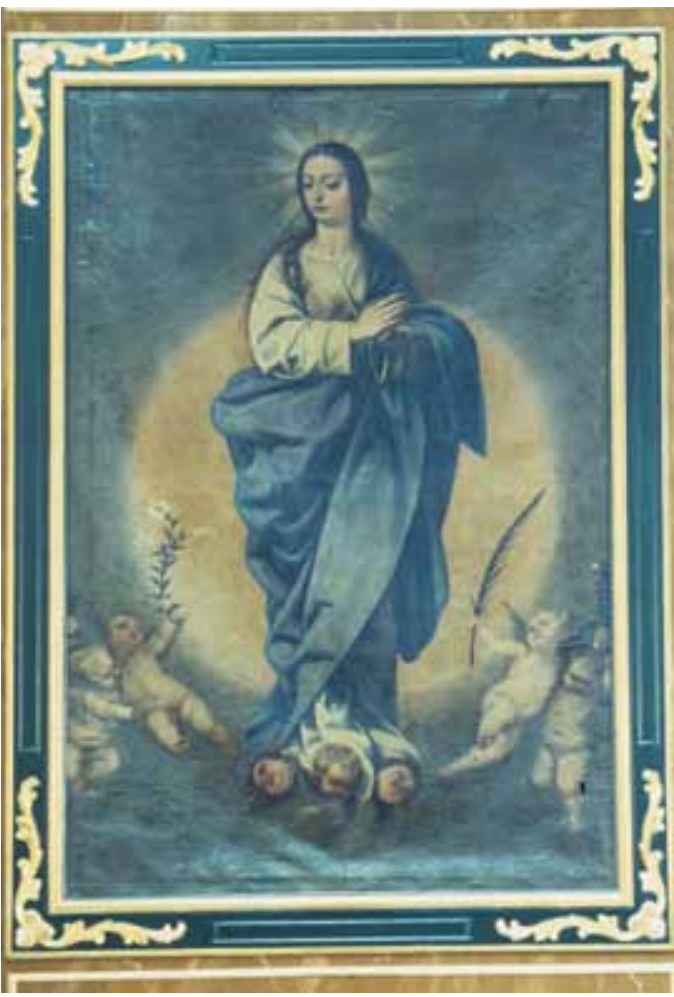

Inmaculada Concepción de la ermita de la Virgen del Socorro en Tíjola
Otro dato importante a la hora de afrontar el trabajo de inventario es no perder de vista la histórica estructura eclesiástica de la provincia, muy diferente a la actual debida a la reforma del año 1956, por la que determinadas comarcas formaron parte del arzobispado de Granada, obispado de Almería y obispado de CartagenaMurcia. El valle del río Almanzora prácticamente en su totalidad perteneció al obispado almeriense, salvo Huércal Overa, que fue tierra vinculada al obispado de Cartagena-Murcia. Además, estas relaciones son importantes, debido a que también explican por qué estas comarcas se abastecieron de obras procedentes fundamentalmente de los focos artísticos de Granada y Murcia, sobre todo ante la inexistencia de una escuela artística local.

En la comarca del valle del río Almazora se han trabajo 11 poblaciones, distribuidas tanto por las sierras del alto Almanzora como en la franja litoral, inventariándose 16 inmuebles y 594 bienes muebles. Los edificios más significativos han sido los de Albox, Tíjola, Cuevas del Almanzora, Vera y Huércal Overa, ya que son los que conservan un mayor número de piezas inventariadas.

La iglesia de Santa Maria y el monasterio del Saliente en Albox, edificios barrocos del siglo XVIII, a pesar de las importantes pérdidas patrimoniales que han sufrido, conservan aún la esencia de sus programas artísticos, donde la integración de las artes y la armonía entre función y estética fueron las notas dominantes. Por esta razón, se ha procedido a inventariar todas las piezas metálicas que poseen, como rejas, barandas, además del púlpito del santuario del Saliente, realizado también en este material.
Igualmente significativo es el mobiliario realizado en madera, con obras excelentes como las puertas de la portada principal, de 1741 y el cancel de la iglesia de Santa Maria, y la carpintería del Saliente que, aunque cuenta con puertas excesivamente restauradas, todavía es posible valorar en ellas la riqueza de sus diseños, basados en motivos vegetales y geométricos policromados en rojo y verde. En la iglesia de Santa María prácticamente el resto de su dotación mueble es neobarroca de la segunda mitad del siglo XX, salvo el retablo de Nuestro Padre Jesús Nazareno que es una obra del siglo XVIII. En cuanto al santuario del Saliente la pieza más importante es la imagen de Nuestra Señora del Buen Retiro de los Desamparados, no sólo por la devoción que despierta sino también por la calidad artística que atesora. Datada en el siglo XVIII, es una pequeña talla de madera policromada, de controvertido origen e iconografía, representada de pie sobre la luna, con el rostro y mirada ascendente, coronada y sostenida por dos ángeles mancebos.

En Tíjola se han inventariado la iglesia parroquial y la ermita de Nuestra Señora del Socorro. La iglesia de Santa María es un edificio mudéjar construido entre 1660 y 1665, a cuya estructura primigenia se fueron añadiendo capillas durante el último tercio del siglo XVII y principios del XVIII, conservándose de este periodo una interesante colección de escudos y heráldicas realizados en mármol, como las armas del Obispo don Luis Venegas y Figueroa, el escudo del marqués de Villena y las armas de las familias TorreMarin y Herrán. También merecen especial atención los cuatro retablos del siglo XVIII que se hallan en su disposición original, si bien las imágenes que acogen son obras de factura reciente. 


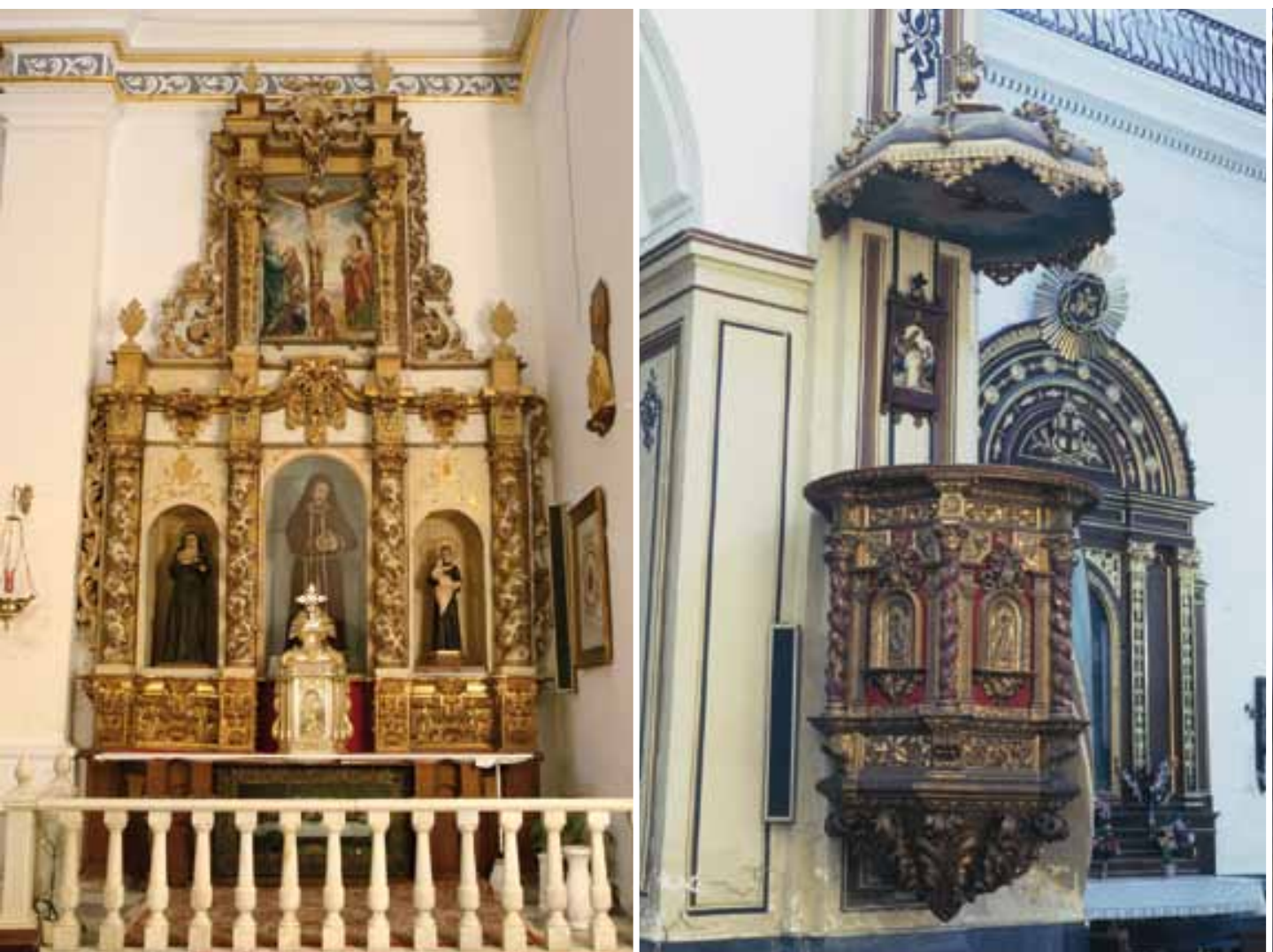

Retablo de Nuestro Padre Jesús Nazareno de la iglesia de Santa María en Albox
Púlpito de la iglesia de la Encarnación en Cuevas del Almanzora

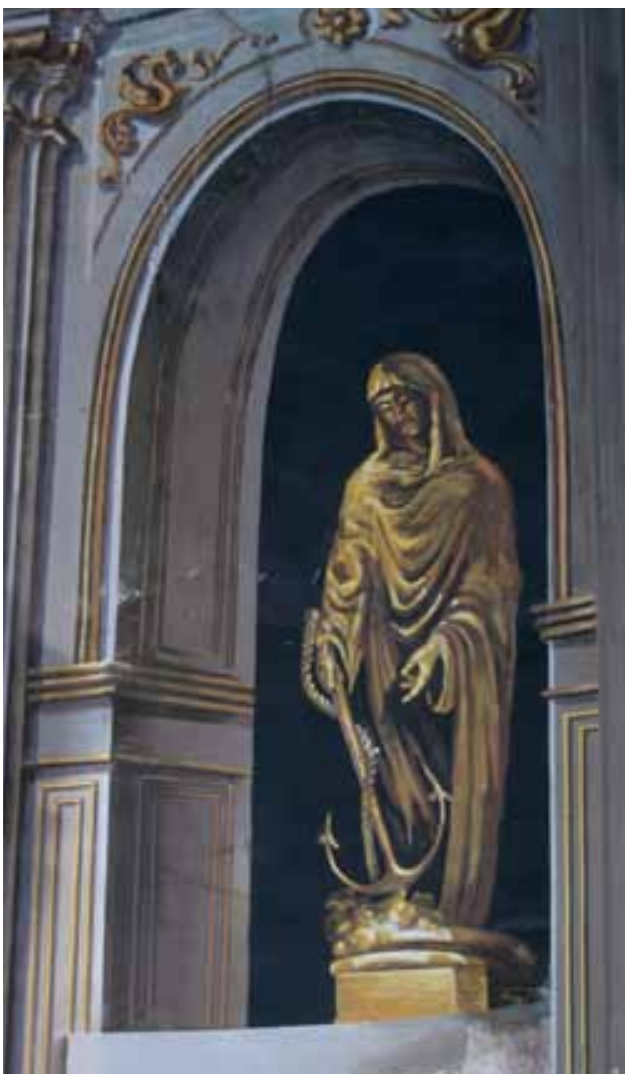

Alegoría de la Esperanza de la iglesia de la Encarnación en Cuevas del Almanzora

\section{Bibliografía}

ESPINOSA SPÍNOLA, G. (2007) El Barroco en Almeria. En El Barroco en Andalucía. Sevilla: Junta de Andalucia, Consejeria de Cultura, 2007, pp. 11-30 ESPINOSA SPÍNOLA, G. (2008) Artes decorativas y suntuarias del Barroco almeriense. En La Almería Barroca. Almeria: Junta de Andalucia, Diputación de Almeria, 2008, pp. 207-232

ESPINOSA SPÍNOLA, G. et ál. (2006) Guía artística de Almería y su Provincia. Sevilla: Instituto de Estudios Almerienses; Fundación José Manuel Lara, 2006 NICOLÁS MARTÍNEZ, M. a (2008) Sobre la pintura y la escultura barroca en Almería. Propuestas para su estudio y revisión. En La Almería Barroca. Almería: Junta de Andalucia, Diputación de Almería, 2008, pp. 143-176

TORRES FERNÁNDEZ, M. ${ }^{a}$ R. (2007) El Arte de los Siglos del Barroco en la Provincia de Almería. En Andalucía Barroca: exposición Itinerante. Sevilla: Consejería de Cultura, Junta de Andalucía, 2007, pp.150-165

TORRES FERNÁNDEZ, M. ${ }^{a}$ R. (2008) Arquitectura eclesial y retablistica de los siglos XVII y XVIII. En La Almería Barroca. Almeria: Junta de Andalucia, Diputación de Almería, 2008, pp. 33-84

UREÑA UCEDA, A. (2008) El barroco en el valle del Almanzora: entre lo granadino y lo murciano. En La Almería Barroca. Almeria: Junta de Andalucia, Diputación de Almería, 2008, pp. 233-362

W. AA. (2007) Luminaria, dos milenios de cristianismo en Almería. Salamanca: Gráficas Lope, 2007

\section{Albox}

Iglesia parroquial de Santa María: 65 bienes muebles Santuario de Nuestra Señora del Buen Retiro de los Desamparados de El Saliente: 129 bienes muebles

\section{Arboleas}

Iglesia parroquial de Santiago: 19 bienes muebles

\section{Cuevas del Almanzora}

Iglesia parroquial de la Encarnación: 137 bienes muebles Fines

Iglesia parroquial de Nuestra Señora del Rosario: 7 bienes muebles

\section{Huercal Overa}

Iglesia parroquial de Nuestra Señora de la Asunción: 57 bienes muebles

Lúcar

Iglesia parroquial de Santa María: 18 bienes muebles Ermita: 3 bienes muebles

Pulpí

Iglesia parroquial de San Miguel: 9 bienes muebles Purchena

Iglesia parroquial de San Ginés: 28 bienes muebles Serón

Iglesia parroquial de la Anunciación: 37 bienes muebles Ermita de Nuestra Señora de los Remedios: 4 bienes muebles Tíjola

Iglesia parroquial de Santa María: 43 bienes muebles Ermita de San Sebastián: 2 bienes muebles

Ermita de la Virgen del Socorro: 14 bienes muebles Vera

Iglesia parroquial de Nuestra Señora de la Encarnación: 81 bienes muebles 